\title{
Mercury in soil surrounding medieval human skeletons
}

Kaare Lund Rasmussen ${ }^{1 *}$, Lilian Skytte ${ }^{1}$, Nadja Ramseyer ${ }^{1}$ and Jesper Lier Boldsen ${ }^{2}$

\begin{abstract}
Studying medieval skeletons is a direct way to obtain information about life in medieval societies with very little other information available about the living conditions of ordinary people. In this paper we investigate how $\mathrm{Hg}$ is distributed in soil samples surrounding seven medieval skeletons excavated at the cemeteries Lindegaarden in Ribe and Ole Wormsgade in Horsens, both situated in Jutland, Denmark.

The analyses have been performed using Cold Vapour Atomic Absorption Spectroscopy (CV-AAS). The results show systematic variations of the $\mathrm{Hg}$ concentrations in soil samples as a function of distance extending horizontally from the femur. Two individuals showed soil Hg concentrations at the background level, below ca. $100 \mathrm{ng} \mathrm{g}^{-1}$, whereas soil samples surrounding the other five individuals exhibited much larger $\mathrm{Hg}$ concentrations.

Our interpretation of the data is that in general the $\mathrm{Hg}$, which was once situated in the soft tissue, is still present and in-place in the soil now surrounding the skeleton. Due to the overburden of ca. 3 feet of topsoil the residual of the soft tissue has been condensed into the mid-plane of the flattened corpse. The decomposed soft tissue now mixed with the soil can in this way be sampled near the femur as well as from the inner organs: the kidneys, the liver and the lungs.
\end{abstract}

Keywords: Human bones, Medieval, Mercury, Soil, Decomposed tissue

\section{Introduction}

Medieval people were subjected to an $\mathrm{Hg}$ exposure, which can be divided into a global background exposure and occasional much higher point source exposures of cultural origins. In non-monastic environments the individuals were mostly exposed to $\mathrm{Hg}$ in connection with treatment of diseases, a modus operandi already practiced by the Romans as described by Pliny the Elder [1] (see further details in Rasmussen et al. [2]). In femoral samples the medieval background exposure gave rise to concentrations levels of between 10 and $100 \mathrm{ng} \mathrm{g}^{-1}$, while individuals exposed to $\mathrm{Hg}$ in connection with medication may exhibit $\mathrm{Hg}$ concentrations up to several thousand $\mathrm{ng} \mathrm{g}^{-1}[2,3]$.

Under normal conditions in Northern European medieval cemeteries only the bones are preserved; the decayed soft tissue is now normally part of the soil surrounding the skeleton. However, it seems that the $\mathrm{Hg}$ which was

\footnotetext{
* Correspondence: klr@sdu.dk

'Institute of Physics, Chemistry and Pharmacy, University of Southern Denmark, Campusvej 55, DK-5230 Odense M, Denmark

Full list of author information is available at the end of the article
}

originally present in the soft tissue is now often still in-place and preserved in the soil. Rasmussen et al. [2] reported $\mathrm{Hg}$ in soil profiles of three individuals extending horizontally and vertically away from the femur, thus sampling what was previously the soft tissue, and excluded the possibility of diagenetic transport of $\mathrm{Hg}$ in this connection. The most likely explanation for $\mathrm{Hg}$ still being inplace in a situation where so many other compounds and elements have been dissipated by diagenesis is that $\mathrm{Hg}$ with its high affinity of $\mathrm{S}$ very soon ended up as $\mathrm{HgS}$, which is very stable indeed in the geochemical environment [4]. Here we present more measurements of $\mathrm{Hg}$ in soil surrounding medieval skeletons and present a further discussion of how it is preserved and how the concentrations can be interpreted in accordance with the chemical life history hypothesis $[3,5]$.

\section{Excavation site, materials and sampling strategy}

The individuals investigated in the present work are from two cemeteries in two medieval towns in Jutland, Denmark. The first is Ribe, which is one of Denmark's oldest towns, if not the oldest [6-8]. The investigated
(C) Chemistry Central

C 2013 Rasmussen et al.; licensee Chemistry Central Ltd. This is an Open Access article distributed under the terms of the Creative Commons Attribution License (http://creativecommons.org/licenses/by/2.0), which permits unrestricted use,

distribution, and reproduction in any medium, provided the original work is properly cited. 

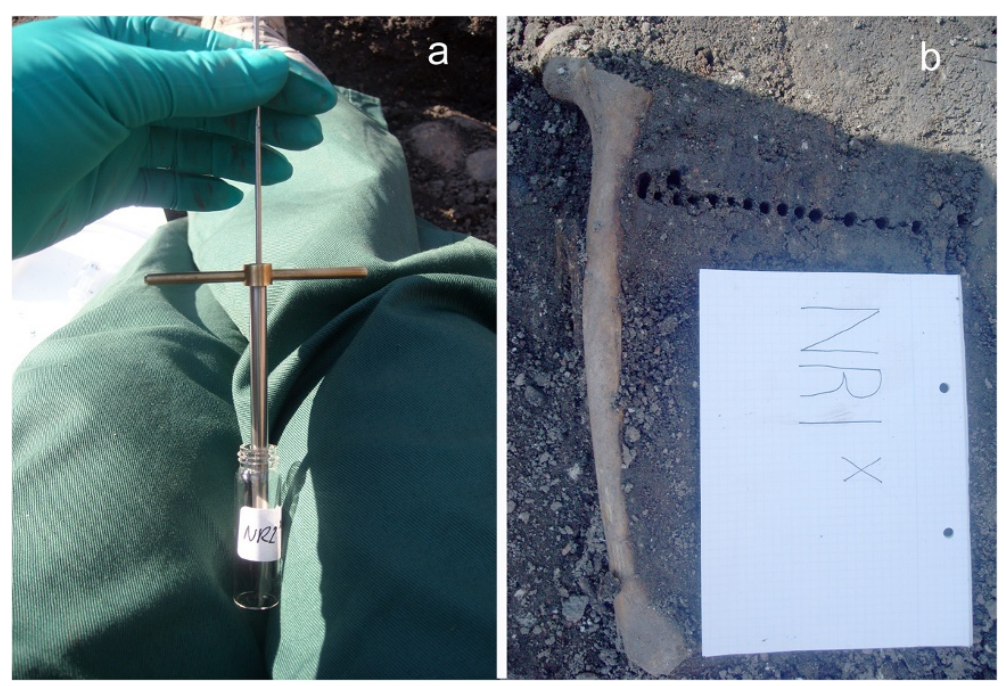

Figure 1 Fieldwork securing the soil samples. a: Sample being transferred from the in-house build stainless soil drill to a glass vial. b: A femur bone with adjacent holes in the soil after sampling. The distances between the holes are $1 \mathrm{~cm}$.

graves are from the cemetery Lindegaarden adjacent to the cathedral and probably from the $11^{\text {th }}$ century. The site was excavated in 2008 and 2009 by Sydvestjyske Museer (excavation code ASR13, Additional file 1). The second site is Ole Wormsgade in Horsens, a large medieval town further north in Denmark $[9,10]$. The cemetery excavated in Ole Wormsgade probably belonged to the parish church, Church of Our Lady, and the graves investigated are from the period 1250 to the protestant reformation in 1536 . The cemetery was excavated by Horsens Museum in 2009 (excavation code HOM 1649, Additional file 2).

The samples were in all cases taken with kind permission from the archaeologists during the excavation, when the skeleton was halfway exposed in the plane. An inhouse build handheld hollow and sharp drill was used for taking cylindrical soil samples of $6 \mathrm{~mm}$ in diameter and ca. $2 \mathrm{~cm}$ in length and weighing 1-2 gram (see Figure 1a). The stainless steel tool was decontaminated in distilled water between each sampling in order to rid the utensil of any $\mathrm{Hg}$ cross contamination.

The sampling strategy was that the samples were taken at the precise time during the excavation when the upper parts of the skeleton were visible in the excavated plane, but before the soil of the mid-plane of the corpse was removed. We took a vertical miniature drill core ca. $2 \mathrm{~cm}$ in length and thus covered the majority of the remains of the decomposed soft tissue which is compressed in the vertical direction due to the overburden of the ca. 3 feet of topsoil. Approximately 10 samples were taken horizontally away from the femur, $1 \mathrm{~cm}$ apart as shown by the example in Figure $1 \mathrm{~b}$ and schematically in Figure 2. In some instances further soil samples were procured directly downwards after the femur was

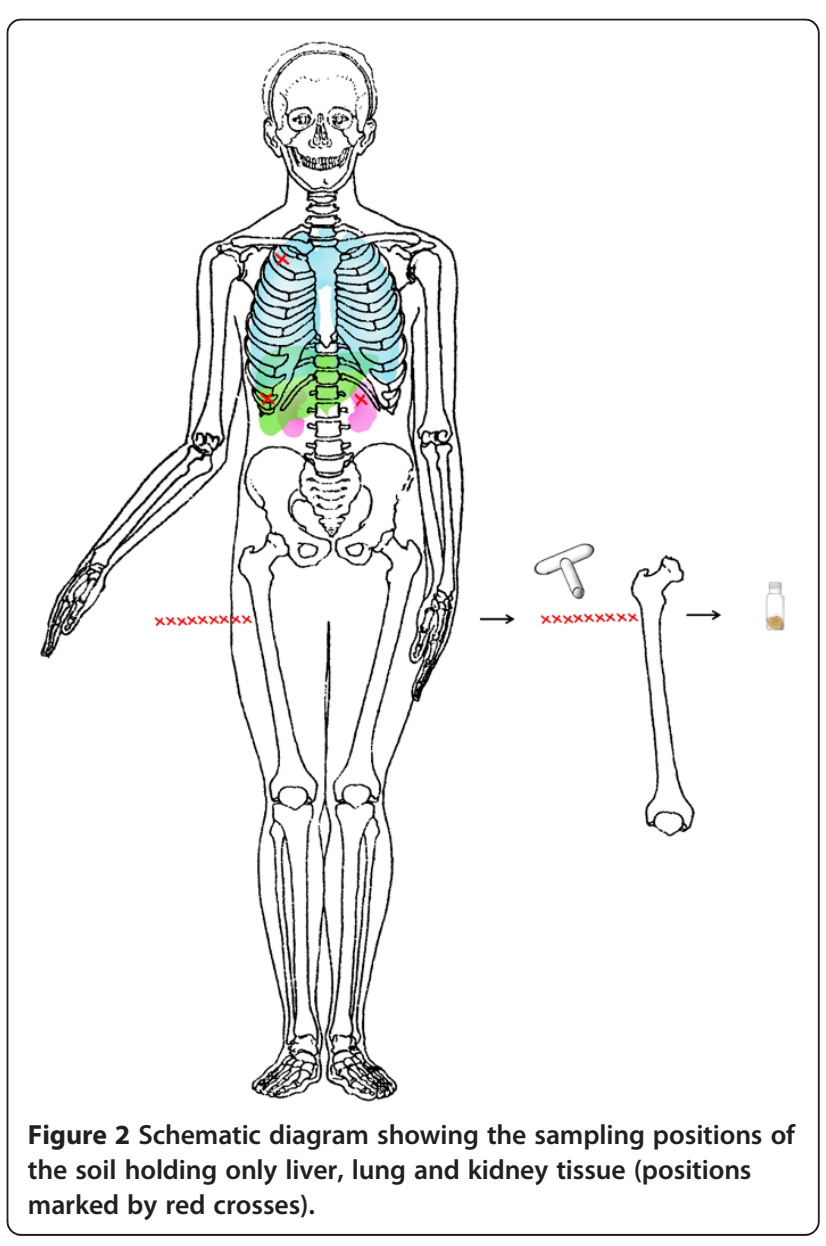


removed, some of these vertical profiles are shown in the diagrams marked "v". Soil samples were also procured from what were once the inner organs: kidneys, liver, and lungs. These sampling positions were chosen at places where no other inner organs overlapped them in a condensed vertical view of the corpse. The sampling positions of the inner organs are indicated with red crosses in the schematic diagram in Figure 2. The liver samples were taken 2 to $7 \mathrm{~cm}$ right laterally from the tenth thoracic vertebra. The lung samples were taken ca. $1 \mathrm{~cm}$ below the first rib, and the kidney samples were taken outside the second lumbar vertebra under the twelfth rib.

The samples were transferred to and sealed in precleaned glass vials and stored in a refrigerator at ca. 5 degree $\mathrm{C}$ until the time of analysis, as recommended by Ure [11]. Prior to dissolution, the soil samples were homogenized according to the grab-sampling procedure developed by Pierre Gy [12]. The mechanically homogenized bulk soil sample was placed along an in-house build aluminum-shelf. Ten subsamples, each of ca. $40 \mathrm{mg}$, were taken out randomly with an in-house build stainless steel grabber, ca. $4 \mathrm{~mm}$ wide and with sharp, vertical walls. After grabbing, the ten subsamples were mixed and homogenized. The utensils were cleaned and exposed to an ethanol flame after each sample.

The bone samples were decontaminated and sampled as described in Rasmussen et al. [2,3] and they were in all cases from the femur. Only compact bone tissue was sampled. In this study we report data from seven individuals. These were selected in an illustrative way amongst a total of 19 individuals studied. Out of 5 individuals from Ribe, 4 were highly exposed to $\mathrm{Hg}$ and one moderately exposed to $\mathrm{Hg}$; out of 14 individuals from Horsens, 3 were highly exposed, 4 were moderately exposed, and 7 were not exposed to $\mathrm{Hg}$ above background levels.

\section{Analytical techniques Dissolution}

The ca. $400 \mathrm{mg}$ of grab-sampled and homogenized soil was transferred to a pressure liner from an Anton Paar Microwave oven digestion system together with $3 \mathrm{~mL}$ analytical grade concentrated $\mathrm{HNO}_{3}$ and $3 \mathrm{~mL}$ analytical grade concentrated $\mathrm{HCl}$. The samples were then digested using a temperature program consisting of 15 minutes ramping up the temperature using $800 \mathrm{~W}, 15$ minutes hold time at $180^{\circ} \mathrm{C}$, and finally ca. 1 hour of cooling time [13]. Using this method, $\mathrm{Gu}$ et al. [14] achieved a yield of between 79 and 109\% $\mathrm{Hg}$ recovery on soil samples of known Hg concentration. After cooling, the samples were filtrated through a $0.22 \mu \mathrm{m}$ cellulose acetate Qmax filter, which was eluted afterwards in $10 \mathrm{~mL} 1.5 \%$ analytical grade $\mathrm{HNO}_{3}$ diluted in distilled water. Both the sample and the rinse solution were transferred to a volumetric flask. Finally the sample was diluted with distilled water until $50.00 \mathrm{~mL}$. The final $\mathrm{HNO}_{3}$ concentration in the diluted sample was about $1 \%$, which is well suited for analysis in the CV-AAS.

The bones samples were dissolved using ca. $70 \mathrm{mg}$ of bone sample in $6 \mathrm{~mL} \mathrm{HNO} 3,3 \mathrm{~mL} \mathrm{H}_{2} \mathrm{O}_{2}$ and $1 \mathrm{~mL} \mathrm{HCl}$, all concentrated and all of analytical grades.

\section{CV-AAS}

Mercury was measured by CV-AAS (cold vapour atomic absorption spectroscopy) on a dedicated mercury analyser, a Flow Injection Mercury System (FIMS-400) by PerkinElmer equipped with an Au-trap. Two hours prior to analysis $1 \mathrm{~mL}$ of concentrated $\mathrm{KMnO}_{4}$ was added to $10 \mathrm{~mL}$ of dissolved sample in order to maintain $\mathrm{Hg}$ on ionic form. The sample was then diluted to $20 \mathrm{~mL}$. In the reaction chamber of the FIMS-400 the $\mathrm{Hg}$ was released as vapour by adding $\mathrm{NaBH}_{4}$. All samples were measured in triplicate. The overall uncertainties, i.e. including reproducibility and dilution, was estimated to be ca. $\pm 10 \%(1 \sigma)$, and the LOD was ca. $20 \mathrm{ng} \mathrm{g}^{-1}$ for a human bone sample of ca. $70 \mathrm{mg}$ and ca. $5 \mathrm{ng} \mathrm{g}^{-1}$ for a $400 \mathrm{mg}$ soil sample.

An in-house human bone standard was dissolved daily together with the bone samples and included in the daily runs in order to monitor any drift in the systems. However, the inhomogeneity of the in-house standard ranged in $\mathrm{Hg}$ from 70 to $100 \mathrm{ng} \mathrm{g}^{-1}$ and was in all normal cases larger than the analytical uncertainty.

\section{Results}

The results of the $\mathrm{Hg}$ measurements are listed in Table 1 and shown in the diagrams of Figures 3, 4, 5, 6, 7, 8, 9, where the analysis of the bone sample is depicted to the left in the diagrams. The $\mathrm{x}$-axis scale in the diagrams signifies the distances in $\mathrm{cm}$ of the soil samples from the femur - horizontally and vertically (vertically marked with a "v"). To the right is depicted the concentrations of the soil samples from the inner organs. We have attempted to present the data in order of progressively shorter half-lives of $\mathrm{Hg}$ in the tissue types, starting with the longest half-life to the left (the bone sample) and the shortest $\mathrm{Hg}$ half-life to the right (the lung tissue).

In the first example shown in Figure 3 the individual is a 30-40 years old male from Horsens (KLR-7918, grave X1578). He was exposed only to the global Hg background. The threshold level for such non-exposed individuals is approximately $100 \mathrm{ng} \mathrm{g}^{-1}$, a value shown as a dashed line in the diagrams. In the second example shown in Figure 4, the grave of a teenager of age ca. 15 from Horsens (KLR-7915, X1572), the compact bone sample showed a $\mathrm{Hg}$ concentration of ca. $300 \mathrm{ng} \mathrm{g}^{-1}$, which is definitively higher than the threshold value of 
Table 1 Results of the $\mathrm{Hg}$ measurements

\begin{tabular}{|c|c|c|c|c|c|c|c|c|}
\hline Lab-no. KLR- & Grave no. & $\begin{array}{l}\text { Age at } \\
\text { death }(y)\end{array}$ & Sex & $\begin{array}{l}{[\mathrm{Hg}] \pm 1 \sigma} \\
\left(\mathrm{ng} \mathrm{g}^{-1}\right)\end{array}$ & $\begin{array}{l}\text { Soil samples } \\
\text { (distance from } \\
\text { bone in } \mathrm{cm} \text { ) }\end{array}$ & $\begin{array}{c}{[\mathrm{Hg}] \pm 1 \sigma} \\
\left(\mathrm{ng} \mathrm{g}^{-1}\right)\end{array}$ & $\begin{array}{l}\text { Internal organs } \\
\text { sampled }\end{array}$ & $\begin{array}{r}{[\mathrm{Hg}] \pm 1 \sigma} \\
\left(\mathrm{ng} \mathrm{g}^{-1}\right)\end{array}$ \\
\hline \multicolumn{9}{|c|}{ Ole Wormsgade, Horsens } \\
\hline \multirow[t]{8}{*}{7912} & X1526 & $30-40$ & Female & $89 \pm 17$ & 0 & \pm 19 & Lung & $368 \pm 25$ \\
\hline & & & & & 1 & $194 \pm 32$ & & \\
\hline & & & & & 2 & $222 \pm 31$ & & \\
\hline & & & & & 3 & $581 \pm 30$ & & \\
\hline & & & & & 4 & $555 \pm 30$ & & \\
\hline & & & & & 5 & $325 \pm 30$ & & \\
\hline & & & & & 6 & $329 \pm 32$ & & \\
\hline & & & & & 7 & $263 \pm 31$ & & \\
\hline \multirow[t]{14}{*}{7914} & $X 1574$ & $35-45$ & Female & $214 \pm 15$ & 0 & $405 \pm 16$ & Kidney & $924 \pm 26$ \\
\hline & & & & & 0.5 & $314 \pm 25$ & Lung (upper) & $574 \pm 22$ \\
\hline & & & & & 1 & $337 \pm 25$ & Lung (lower) & $593 \pm 21$ \\
\hline & & & & & 1.5 & $304 \pm 25$ & & \\
\hline & & & & & 2 & $446 \pm 28$ & & \\
\hline & & & & & 3 & $367 \pm 24$ & & \\
\hline & & & & & 4 & $381 \pm 25$ & & \\
\hline & & & & & 5 & $236 \pm 25$ & & \\
\hline & & & & & 6 & $417 \pm 25$ & & \\
\hline & & & & & 7 & $313 \pm 26$ & & \\
\hline & & & & & $0(v)$ & $543 \pm 26$ & & \\
\hline & & & & & $1(v)$ & $393 \pm 27$ & & \\
\hline & & & & & $2(v)$ & $292 \pm 26$ & & \\
\hline & & & & & $3(v)$ & $206 \pm 23$ & & \\
\hline \multirow[t]{12}{*}{7915} & X1572 & $15+$ & n.d. & $316 \pm 17$ & 0 & $238 \pm 7$ & & \\
\hline & & & & & 1 & $99 \pm 6$ & & \\
\hline & & & & & 2 & $84 \pm 5$ & & \\
\hline & & & & & 3 & $83 \pm 6$ & & \\
\hline & & & & & 4 & $123 \pm 14$ & & \\
\hline & & & & & 5 & $60 \pm 5$ & & \\
\hline & & & & & 6 & $101 \pm 13$ & & \\
\hline & & & & & 7 & $78 \pm 18$ & & \\
\hline & & & & & 8 & $129 \pm 17$ & & \\
\hline & & & & & 9 & $67 \pm 16$ & & \\
\hline & & & & & 10 & $64 \pm 16$ & & \\
\hline & & & & & $0(v)$ & $156 \pm 7$ & & \\
\hline \multirow[t]{7}{*}{7918} & X1578 & $30-40$ & Male & $124 \pm 8$ & 0 & $93 \pm 11$ & & \\
\hline & & & & & 1 & $93 \pm 6$ & & \\
\hline & & & & & 2 & $157 \pm 13$ & & \\
\hline & & & & & 3 & $54 \pm 4$ & & \\
\hline & & & & & 4 & $57 \pm 4$ & & \\
\hline & & & & & 5 & $84 \pm 5$ & & \\
\hline & & & & & 6 & $81 \pm 5$ & & \\
\hline
\end{tabular}




\begin{tabular}{|c|c|c|c|c|c|c|c|c|}
\hline & & & & & 7 & $162 \pm 13$ & & \\
\hline & & & & & 8 & $52 \pm 4$ & & \\
\hline & & & & & $0(v)$ & $94 \pm 22$ & & \\
\hline Lindeg & & & & & & & & \\
\hline 7902 & X1114 & $10-13$ & n.d. & $354 \pm 15$ & 0 & $906 \pm 58$ & Kidney (upper) & $1109 \pm 91$ \\
\hline & & & & & 1 & $1073 \pm 58$ & Kidney (lower) & $1482 \pm 94$ \\
\hline & & & & & 2 & $1100 \pm 57$ & Liver (upper) & $2688 \pm 120$ \\
\hline & & & & & 3 & $1063 \pm 54$ & Liver (lower) & $1454 \pm 93$ \\
\hline & & & & & 4 & $1036 \pm 57$ & Lung (upper) & $1040 \pm 92$ \\
\hline & & & & & 5 & $902 \pm 56$ & Lung (lower) & $975 \pm 93$ \\
\hline & & & & & 6 & $693 \pm 57$ & & \\
\hline & & & & & 7 & $675 \pm 62$ & & \\
\hline & & & & & 8 & $616 \pm 61$ & & \\
\hline & & & & & 9 & $711 \pm 60$ & & \\
\hline 7903 & X1115 & $21-27$ & Male & $225 \pm 12$ & 0 & $539 \pm 97$ & Liver (upper) & $508 \pm 53$ \\
\hline & & & & & 1 & $507 \pm 28$ & Liver (lower) & $481 \pm 54$ \\
\hline & & & & & 2 & $610 \pm 28$ & Lung (upper) & $441 \pm 53$ \\
\hline & & & & & 3 & $684 \pm 99$ & Lung (lower) & $557 \pm 53$ \\
\hline & & & & & 5 & $827 \pm 92$ & & \\
\hline & & & & & 6 & $765 \pm 90$ & & \\
\hline & & & & & 7 & $702 \pm 94$ & & \\
\hline & & & & & 8 & $632 \pm 94$ & & \\
\hline 7904 & X1117 & $14-17$ & Male & $49 \pm 2$ & 0 & $660 \pm 52$ & Kidney & $1139 \pm 67$ \\
\hline & & & & & 1 & $448 \pm 52$ & Liver & $687 \pm 74$ \\
\hline & & & & & 2 & $808 \pm 74$ & Lung (upper) & $497 \pm 75$ \\
\hline & & & & & 3 & $362 \pm 52$ & Lung (lower) & $437 \pm 77$ \\
\hline & & & & & 5 & $418 \pm 50$ & & \\
\hline & & & & & 6 & $488 \pm 50$ & & \\
\hline & & & & & 7 & $207 \pm 56$ & & \\
\hline & & & & & 9 & $127 \pm 84$ & & \\
\hline & & & & & 10 & $160 \pm 55$ & & \\
\hline
\end{tabular}

The uncertainties quoted are the combined \pm 1 standard deviations calculated from a combination of the uncertainty from the calibration curve and the variation from three independent replicate measurements on the same solution. n.d. means not determined.

ca. $100 \mathrm{ng} \mathrm{g}^{-1}$. However, the decayed soft tissue values of the soil samples were at the threshold level. This indicates that this individual was exposed to $\mathrm{Hg}$ earlier in his life, several years prior to death.

Turning to the individuals with a more pronounced $\mathrm{Hg}$ exposure, Figure 5 shows the measurements on KLR-7912, grave X1526, a 30-40 year old woman from Horsens. She experienced an $\mathrm{Hg}$ exposure relatively late in life - no signs of above background $\mathrm{Hg}$ in the compact femur sample. The soil samples next to the femur showed high $\mathrm{Hg}$ concentrations of on average $400 \mathrm{ng} \mathrm{g}^{-1}$, and the lung tissue exhibits about the same concentration. As said the exposure took place relatively late in life, maybe in the last 6 months or so before her death. A similar exposure pattern was seen for the individual in the grave X1115 (KLR-7903) from Ribe, which was that of a 21-27 year old male (Figure 6). The femoral bone sample had an $\mathrm{Hg}$ concentration of ca. $200 \mathrm{ng} \mathrm{g}^{-1}$ and the lung and liver tissues around $500 \mathrm{ng} \mathrm{g}^{-1}$. Here the soft tissue sample next to the femur exhibited a somewhat higher $\mathrm{Hg}$ concentrations of on average $700 \mathrm{ng} \mathrm{g}^{-1}$.

Soaring $\mathrm{Hg}$ concentrations were observed in the last three individuals. In grave X1574 from Horsens, a 35-45 year old woman with lepra and/or tuberculosis (KLR7914, Figure 7) the soil sample next to the femur had an average $\mathrm{Hg}$ concentration of ca. $400 \mathrm{ng} \mathrm{g}^{-1}$, but the lungs 


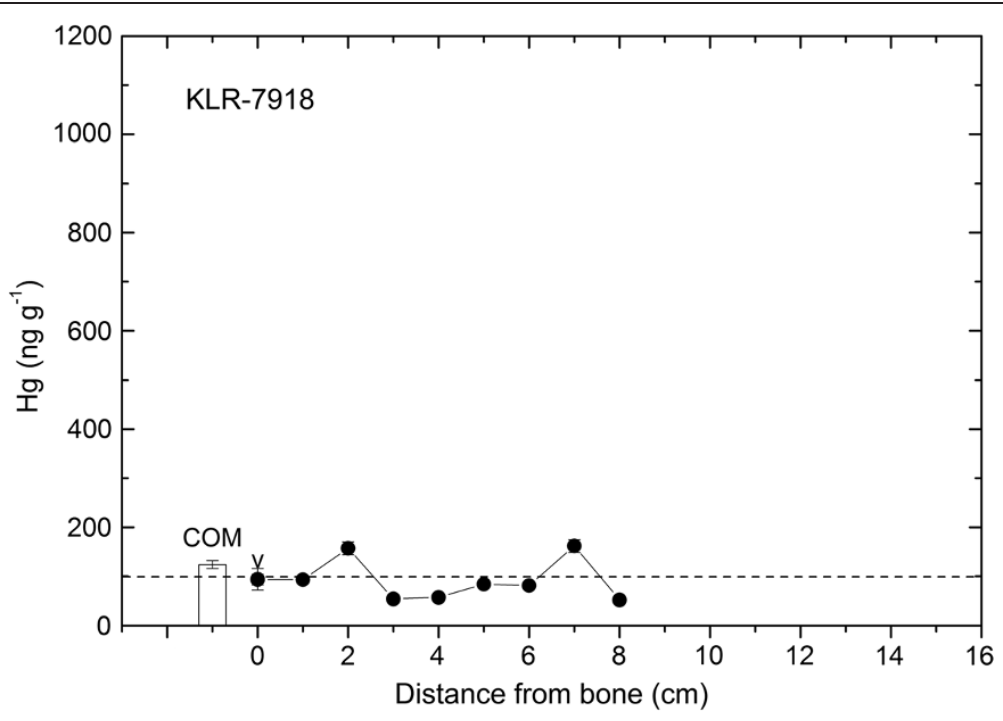

Figure 3 Mercury concentrations determined for bone and soil samples of KLR-7918 from grave X1578 in Ole Wormsgade in Horsens.

exhibited values around $600 \mathrm{ng} \mathrm{g}^{-1}$ and the kidney sample ca. $950 \mathrm{ng} \mathrm{g}^{-1}$. In the grave X1117 from Ribe (KLR7904, Figure 8), a 14-17 year old male, the soil samples next to the femur fell from $800 \mathrm{ng} \mathrm{g}^{-1}$ close to the femur to $100 \mathrm{ng} \mathrm{g}^{-1} 9-10 \mathrm{~cm}$ away, which could indicate that the compaction plane of the corpse did not coincide with excavation plane, and that values around $800 \mathrm{ng} \mathrm{g}^{-1}$ are a more fair representation of the soft tissue values of this individual. Here the soil sample from the kidney showed an $\mathrm{Hg}$ concentration of ca. $1100 \mathrm{ng} \mathrm{g}^{-1}$, the liver 700 and the lungs $400-500 \mathrm{ng} \mathrm{g}^{-1}$. This indicates that the exposure took place shortly before death - maybe a couple of months before, as the $\mathrm{Hg}$ halftime of the kidneys have been determined to ca. 64 days [15].

The most astonishing exposure in our data set is that of KLR-7902, a 10-13 year old child from Ribe in grave $\mathrm{X} 1114$, where the bone $\mathrm{Hg}$ concentration was relatively low, but the soft tissue samples next to the femur varied from 1100 to $700 \mathrm{ng} \mathrm{g}^{-1}$, and the inner organs sported concentrations from ca. 1000 to $2700 \mathrm{ng} \mathrm{g}^{-1}$. One of the two liver samples exhibited the highest value measured: $2688 \pm 120 \mathrm{ng} \mathrm{g}^{-1}$. Following the idea of chemical life history, this individual was exposed to $\mathrm{Hg}$ shortly before death, as it is an educated guess that the turnover time

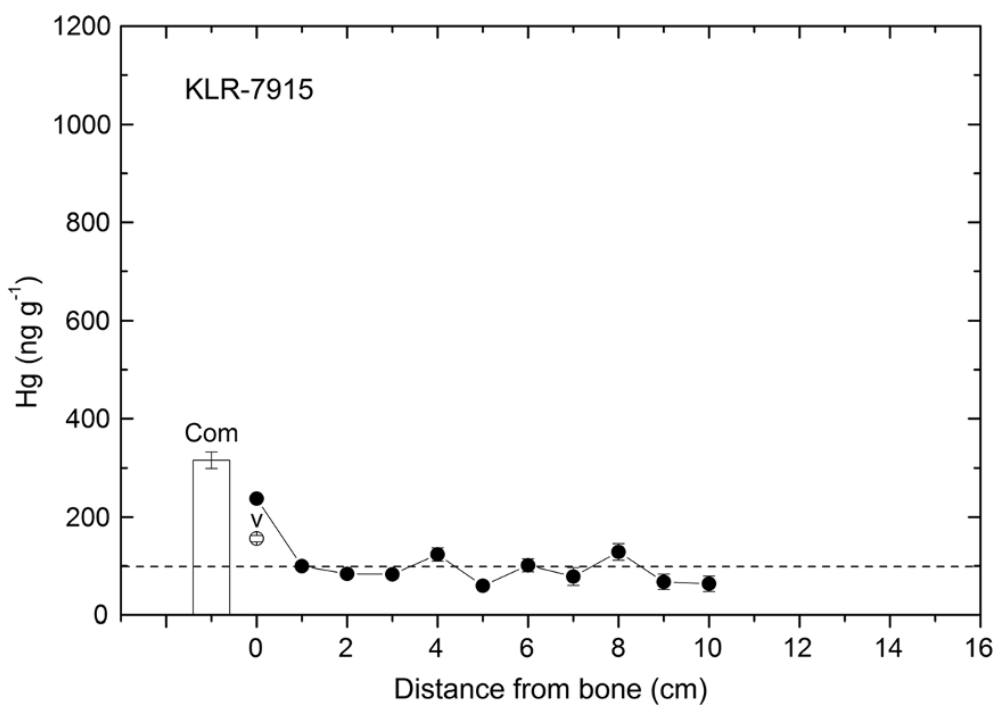

Figure 4 Mercury concentrations determined for bone and soil samples of KLR-7915 from grave X1572 in Ole Wormsgade in Horsens. 


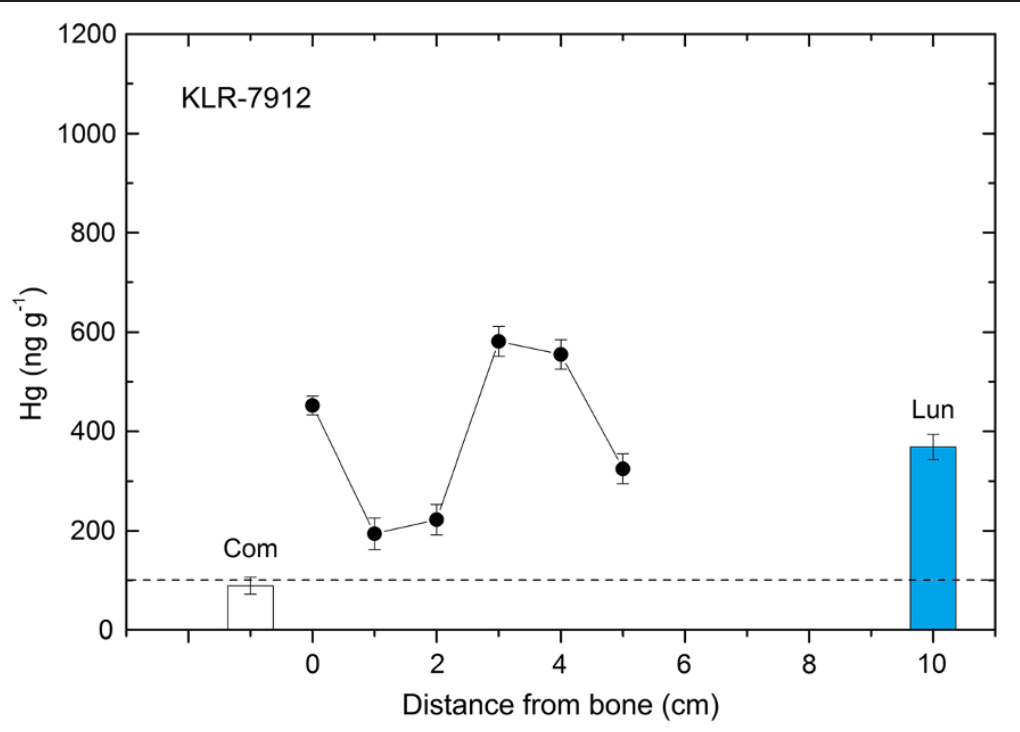

Figure 5 Mercury concentrations determined for bone and soil samples of KLR-7912 from grave X1526 in Ole Wormsgade in Horsens.

of the liver is somewhere between those of the 64 days of the kidneys and the 1.7 days of the lungs [15].

\section{Discussion}

\section{Mercury recovery and lack of diagenesis}

The basic reason that the $\mathrm{Hg}$ is still in-place in the soil is probably the high affinity of $\mathrm{Hg}$ to $\mathrm{S}$, which causes the strong binding of $\mathrm{HgS}$ not easily mobilized in the geochemical environment [4]. Irrespective of whether the $\mathrm{Hg}$ was present in organic or inorganic form while the individual was alive, it is likely to be precipitated as $\mathrm{HgS}$ after the decomposition of the corpse.

The fact that some individuals (14 in the whole study) exhibited $\mathrm{Hg}$ background levels both in the bones and in the soil gives further credence to our interpretation that elevated $\mathrm{Hg}$ concentrations in the soil adjacent to some of the other medieval skeletons are indeed caused by the deposition of $\mathrm{Hg}$ from the now decomposed soft tissue. Yet another factor giving credence to the interpretation is that of the shadow zone. When a corpse undergoes decomposition it is compacted by the overburden leaving the soft tissue flattened in the vertical direction. The process is depicted schematically in Figure 10, which shows three phases of the compaction. Two shadow zones arise during the compaction near the femur (marked "s" in Figure 10). In the shadow zone the compaction is less effective than at other places further away from the femur due to the shadow created by the

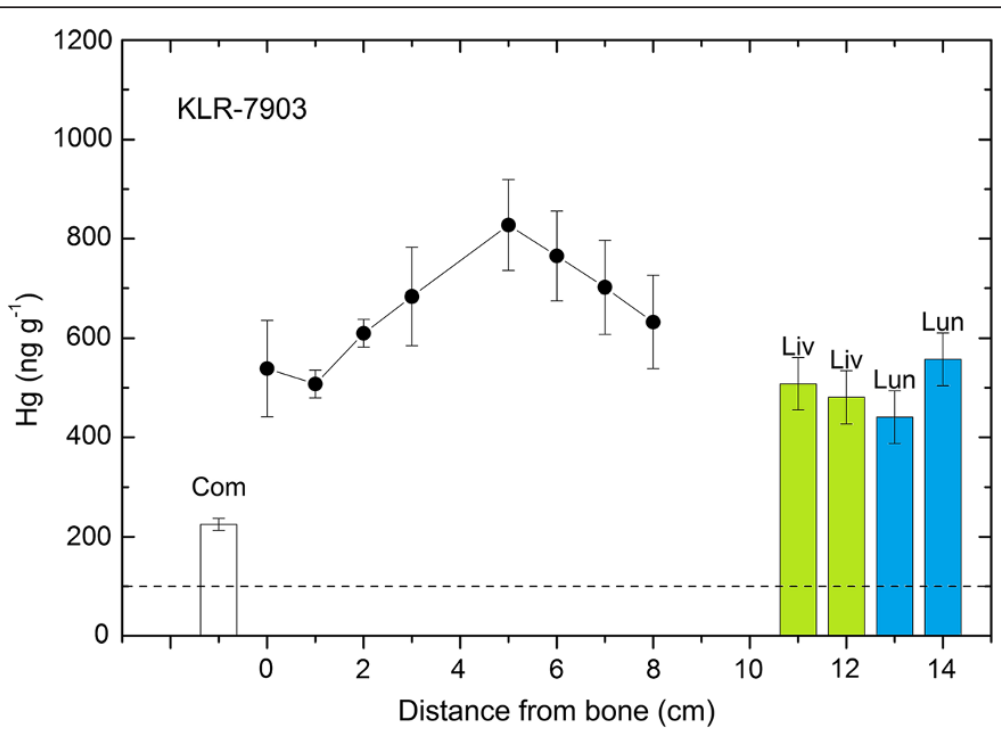

Figure 6 Mercury concentrations determined for bone and soil samples of KLR-7903 from grave X1115 in Lindegaarden in Ribe. 


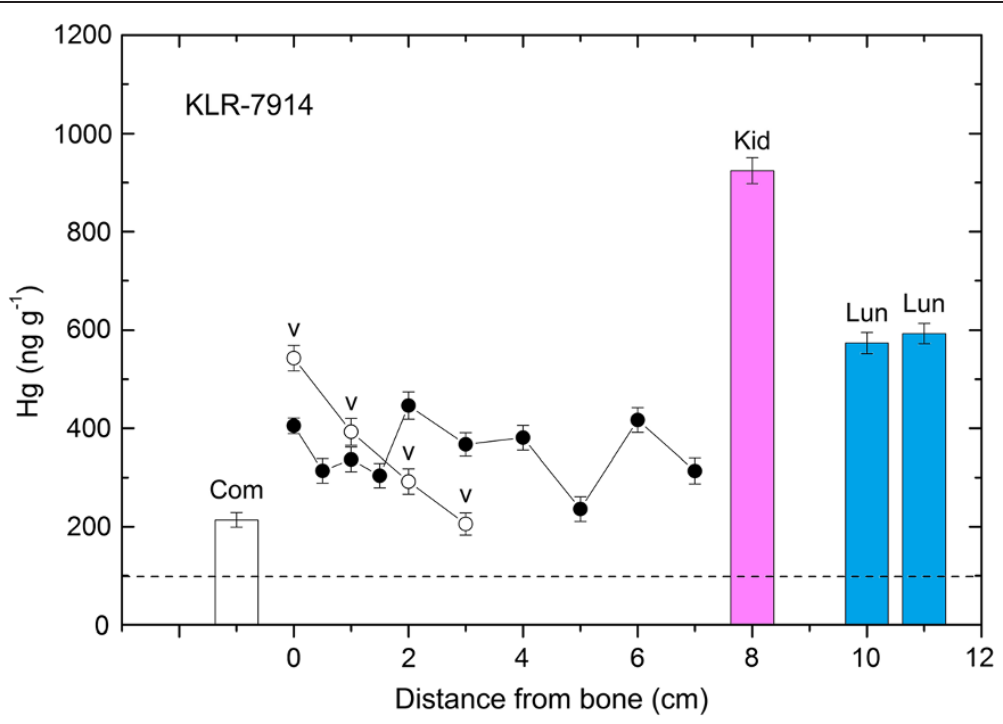

Figure 7 Mercury concentrations determined for bone and soil samples of KLR-7914 from grave X1574 in Ole Wormsgade in Horsens.

large bone, which does not take part in the compaction ( $\mathrm{a}, \mathrm{b}$ and $\mathrm{c}$ ). This variation in the compaction of the corpse creates a variation in the concentration of $\mathrm{Hg}$ with the approximate shape of a sine wave. Such a variation in the $\mathrm{Hg}$ concentration as a function of distance to the femur is seen fully developed in Figure 9, but is also discernible in Figures 5 and 6 . Had the $\mathrm{Hg}$ not been present and in-place, it is very unlikely such a systematic variation should occur.

But how about the soil samples of the inner organs: lungs, liver and kidneys - do the $\mathrm{Hg}$ concentrations determined in the soil really give a fair picture of the $\mathrm{Hg}$ concentrations of these organs when the individual was alive? In modern man it has been shown that the clearance of $\mathrm{Hg}$ from the human body gives rise to high concentrations of $\mathrm{Hg}$ in the kidneys and in the liver. Hac et al. [16] reported an average $\mathrm{Hg}$ concentration of $29.9 \pm 22.0 \mathrm{ng} \mathrm{g}^{-1}$ in liver tissue samples from 46 suddenly deceased modern day Polish citizens, while Iyengar and Woittiez [17] found liver $\mathrm{Hg}$ concentrations ranging from 33-490 $\mathrm{ng} \mathrm{g}^{-1}$ in ten modern individuals. Baselt [18] reported normal ranges in modern man as follows: lung 20-300, liver $160-1300$ and kidney 200-2600 all $\mathrm{ng} \mathrm{g}^{-1}$. All the numbers reported in these modern studies are within the same order of magnitude as the concentrations reported in this study for soil samples. Although these similarities are striking, it is very difficult to make a direct translation between the

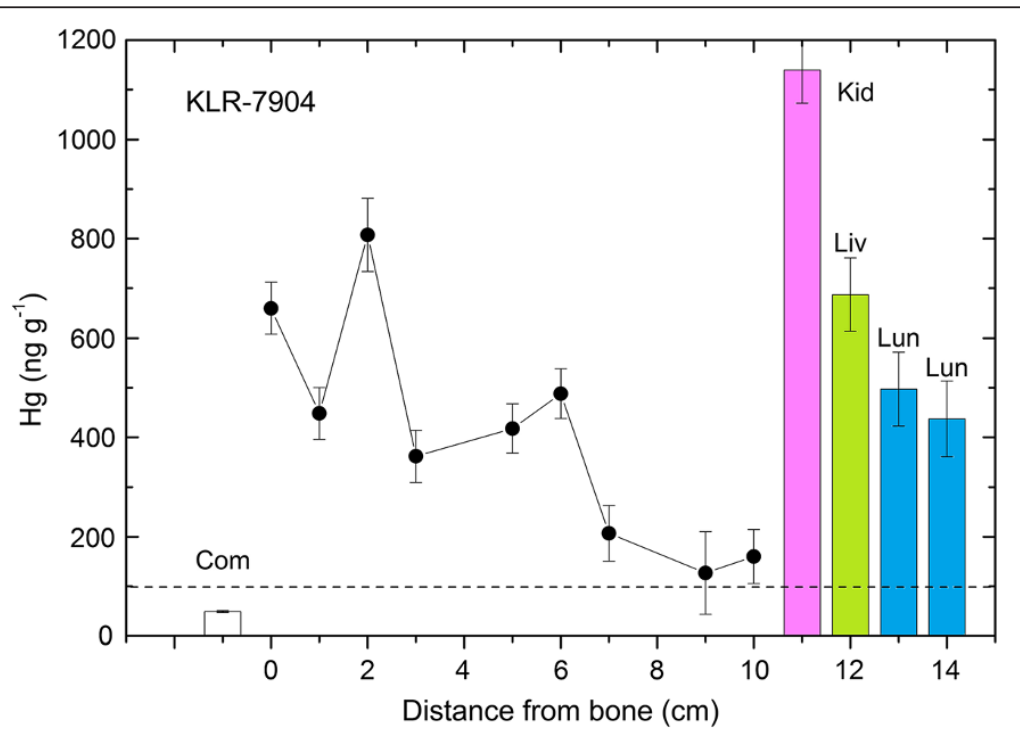

Figure 8 Mercury concentrations determined for bone and soil samples of KLR-7904 from grave X1117 in Lindegaarden in Ribe. 


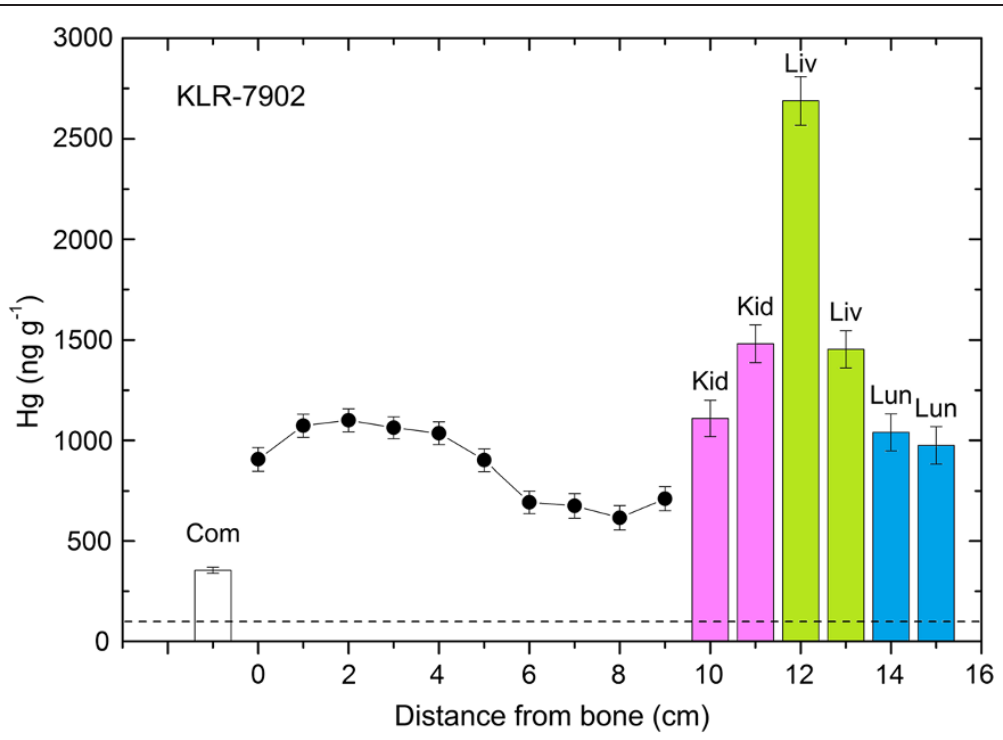

Figure 9 Mercury concentrations determined for bone and soil samples of KLR-7902 from grave X1114 in Lindegaarden in Ribe.

$\mathrm{Hg}$ concentrations measured in the soil to the $\mathrm{Hg}$ concentrations in the once living soft tissue.

\section{Chemical life history}

The consequences of the measurements and interpretations presented here is that the chemical life history hypothesis (see Rasmussen et al. [3] and Skytte and
Rasmussen [5]) for $\mathrm{Hg}$ can be extended to encompass times in life later than the $5-10$ years revealed by the compact femur bone [19]. In case of the kidneys the $\mathrm{Hg}$ half-life is 64 days and for the lungs 1.7 days (Hursh et al. [15]). It is not clear precisely what the half-lives are of the other soft tissues like liver and muscles, although it is probably safe to assume that they are measured in days.

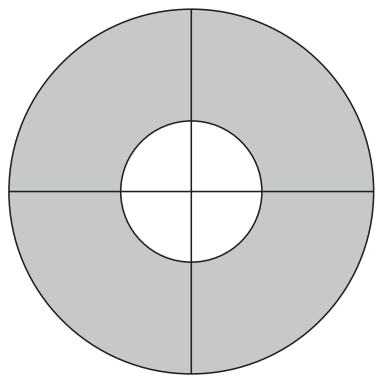

a

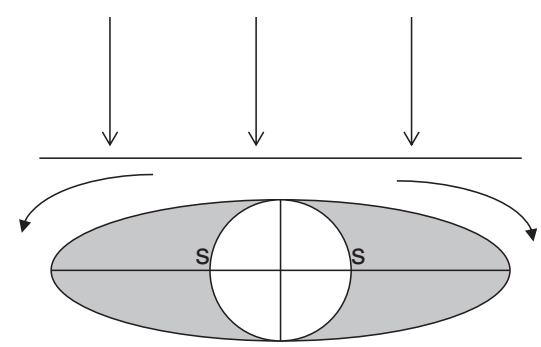

b

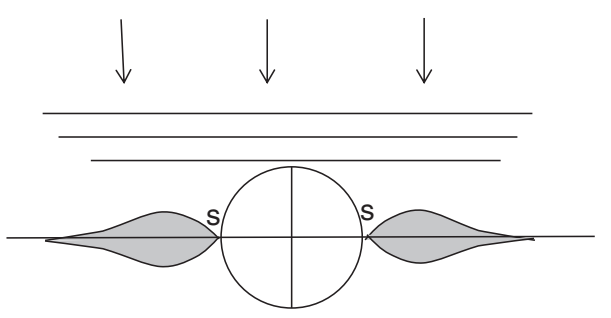

C

Figure 10 Schematic diagram depicting three phases of the compaction of the soft tissues of a corpse. The two shadow zones caused by the intact femur are marked with "s". The white central area signifies the femur bone, and the shaded circle surrounding the bone signifies the soft tissue with a content of $\mathrm{Hg}$. 


\section{Conclusions}

We present measurements of $\mathrm{Hg}$ in soil samples near the skeletons of seven medieval individuals from two Danish cemeteries, Lindegaarden in Ribe and Ole Wormsgade in Horsens. A sample of femoral bone and a series of adjacent soil samples near the femur were procured for each individual, as well as soil samples from positions which were once kidneys, liver and lungs, whenever these positions could be located with certainty in the field.

Two individuals showed no excess $\mathrm{Hg}$ exposure in the soil samples above the background level of ca. $100 \mathrm{ng} \mathrm{g}^{-1}$. Two individuals had moderately high $\mathrm{Hg}$ concentrations in the soil samples, and three exhibited exceptionally high $\mathrm{Hg}$ concentrations in the soil samples.

The bone and soil $\mathrm{Hg}$ concentrations are consistent with an interpretation of $\mathrm{Hg}$ from the decomposed soft tissue still being present and in-place in the soil now surrounding the skeleton. The $\mathrm{Hg}$ data can furthermore be interpreted as the exposure history of $\mathrm{Hg}$ through life of the individuals, similar to the interpretations of chemical life history proposed for the skeletal organ by Rasmussen et al. [3] and Skytte and Rasmussen [5]. However, the times in the life of the individuals covered by the soil samples are much nearer to death than is the case for the bones - the kidneys ca. 64 days prior to death and the lungs ca. 1.7 days prior to death. Such data and their interpretation open for new possibilities in deciphering the lives of single individuals living in medieval Denmark.

\section{Additional files}

Additional file 1: The geographical position of the excavation at Lindegaarden, Ribe, Denmark.

Additional file 2: The geographical position of the excavation at Ole Wormsgade, Horsens, Denmark.

\section{Competing interests}

The authors declare that they have no competing interests.

\section{Authors' contributions}

KLR coordinated the study and drafted the manuscript. NR performed the fieldwork. LS and NR carried out the chemistry laboratory work. JLB made the anthropological examinations. All authors read and approved the final manuscript.

\section{Acknowledgements}

Morten Søvsøe and Helene Agerskov Madsen from Sydvestjyske Museer and Marie Foged Klemensen from Horsens Museum are sincerely thanked for giving permission to sample the skeletons and for allowing us access to take soil samples while they were working on their excavations. The financial support of the VELUX Foundation to the project '1000 year's people' is gratefully acknowledged.

\section{Author details}

${ }^{1}$ Institute of Physics, Chemistry and Pharmacy, University of Southern Denmark, Campusvej 55, DK-5230 Odense M, Denmark. ${ }^{2}$ Institute of Forensic Medicine, ADBOU, Lucernemarken 20, DK-5260 Odense S, Denmark.
Received: 3 April 2013 Accepted: 9 May 2013

Published: 28 May 2013

\section{References}

1. Pliny the Elder: In The Natural History. Book 29, Chapter 8, Evils attendant upon the practice of medicine. Edited by Bostock J, Riley HT. online edition: http://www.perseus.tufts.edu/hopper/text?doc=Perseus\%3Atext\% 3A1999.02.0137\%3Abook\%3D29\%3Achapter\%3D8.

2. Rasmussen $\mathrm{KL}$, Boldsen $\mathrm{L}$, Kristensen HK, Skytte L, Hansen $\mathrm{KL}, \mathrm{M}$, lholm L, Grootes PM, Nadeau M-J, Eriksen KMF: Mercury levels in Danish medieval human bones. J Archaeol Sci 2008, 35(8):2295-306.

3. Rasmussen KL, Skytte L, Pilekær C, Lauritsen A, Boldsen JL, Leth PM, Thomsen PO: The distribution of mercury and other trace elements in the bones of two human individuals from medieval Denmark - the chemical life history hypothesis. Heritage Science 2013, 1(10). doi:10.1186/ 2050-7445-1-10.

4. Schuster E: The behavior of mercury in the soil with special emphasis on complexation and adsorption processes - A review of the literature. Water Air Soil Pollut 1991, 56(1):667-680.

5. Skytte L, Rasmussen KL: Sampling strategy and analysis of trace element concentrations by ICPMS on medieval human bones - the concept of chemical life history. Rapid Comm Mass Spectrom 2013. In press.

6. Nielsen I: Middelalderbyen Ribe. Projekt Middelalderbyen, Statens humanistiske Forskningsråd. Forlaget Centrum; 1985:216.

7. Nyborg E, Mulvad S: Domkirken i Ribe. Denmark: Ribe Domsogns menighedsråd; 1988:32.

8. Claus F: Ribe Studier. Det Aeldste Ribe: Udgravninger paa nordsiden af Ribe Aa 1984-2000. 2 volumes, Jysk Arkeologisk Selskab skrifter 51. Hojberg, Denmark; 2006:762.

9. Knie-Andersen B: Horsens, købstaden og guldsmedene 1500-1900. Denmark: Horsens Museum; 2006.

10. Reese J: Horsens i 10.000 år, et kalejdoskopisk tilbageblik. Denmark: Kreativt center forlag; 2007.

11. Ure AM: Single extraction schemes for soil analysis and related applications. Sci Total Environ 1996, 178(1-3):3-10.

12. Gy P: Sampling for Analytical Purposes. West Sussex: Wiley; 1993.

13. Kingston HM, Jassie LB: Microwave energy for acid decomposition at elevated temperatures and pressures using biological and botanical samples. Anal Chem 1986, 58(12):2534-2541.

14. Gu W, Zhou CY, Wong MK, Gan LM: Orthogonal array design (OAD) for the optimization of mercury extraction from soils by dilute acid with microwave heating. Talanta 1998, 46(5):1019-29.

15. Hursh JB, Clarkson TW, Cherian MG, Vostal JJ, Mallie RV: Clearance of mercury (Hg-197, Hg-203) vapor inhaled by human subjects. Arch Environ Health 1976, 31(6):302-309.

16. Hac E, Krzyzanowski M, Krechniak J: Total mercury in human renal cortex liver, cerebellum and hair. Sci Total Environ 2000, 248(1):37-43.

17. lyengar $V$, Woittiez J: Trace elements in human clinical specimens: evaluation of literature data to identify reference values. Clin Chem 1988, 34:474-481.

18. Baselt RC: Disposition of Toxic Drugs and Chemicals in Man. Seal Beach, California: Biomedical Publications; 2011

19. ICRP Publication 23: Reference Man: Anatomical, Physiological and Metabolic Characteristics. 1st edition. Holland: Elsevier; 1975.

doi:10.1186/2050-7445-1-16

Cite this article as: Rasmussen et al:: Mercury in soil surrounding medieval human skeletons. Heritage Science 2013 1:16. 